\title{
The legitimate role of Rights Based Approaches to Environmental Conflict Resolution
}

Trevor Daya-Winterbottom, Faculty of Law, University of Waikato

\section{INTRODUCTION}

Rights based approaches to environmental conflict resolution should be viewed from the wider public law context. For example, Martin Loughlin maps the transition from a liberty focused constraint on law based on jurisdiction, to a rights focused approach to "intensive" judicial review based on legality. This sesismic shift away from common law (customary or practical) reasoning adopts a constitutional or statutory approach to describing liberties normatively using the "language of rights", and builds upon the academic tradition that seeks to aid understanding by setting "forth the law as a coherent whole" and "reducing the mass of legal rules to an orderly series of principles". ${ }^{1}$

This paper will explore and critically analyse the effect of these trends on environmental conflict resolution from a trans-national New Zealand perspective. The underlying thesis of this paper is that the possibilities and tensions experienced by the courts in crafting a principled approach to human rights jurisprudence provides a transparent methodology for determing polycentric issues, and that there is a legitimate role for rights based approaches to resolving environmental conflict.

\section{Rights based approaches}

From New Zealand perspective, Christian Whata examined "the language of rights" in the context of special legislation designed to address the civil emergency resulting from the Canterbury

1 Martin Loughlin "Rights Discourse and Public Law Thought in the United Kingdom" in GW Anderson (ed) Rights and Democracy: Essays in UKCanadian Constitutionalism (Blackstone Press, London, 1999) 195, 196, and 206-207. 
IUCN Academy of Environmental Law $14^{\text {th }}$ Colloquium University of Oslo Norway 20-25 June 2016

earthquakes, and the "crisis" regarding freshwater allocation in the Canterbury region due to the absence of an operative regional plan to guide decision-making in relation to resource consent applications under the Resource Management Act 1991 (RMA), the principal environmental law statute in New Zealand. ${ }^{2}$ He noted the problem that: ${ }^{3}$

... the ascendency of value or ethic speak in the last 20 or so years of RMA jurisprudence has come at an apparent price of rights speak. This has diminished the capacity to assert environmental rights per se as fundamental to the human condition, worthy of protection and enforceable. Conversely, the absence of clear treatment of environmental rights has meant that the full implications of legislative changes to the RMA have largely (until very recently) gone unchallenged in the face of laudable, outcome driven, executive policy.

As a result, Whata identified "three kinds of environmental rights", namely: ${ }^{4}$

(1) International environmental rights, for example, the right to a clean environment, sustainable development, and the right to participate in environmental decision-making.

(2) Property rights, for example, quiet enjoyment.

(3) Cultural rights, for example, kaitiakitanga.

Overall, he concluded that: ${ }^{5}$

... in my view executive decision-making affecting the environment inevitably engages underlying environmental rights ... For my part these rights are properly categorised as environmental rights at public law. They are not actionable per se, but are engaged when public law powers derogate from them in an appreciable way. They are an aspect of the rule of law.

2 Christian Whata "Environmental Rights in a Time of Crisis: The Canterbury Experience" (11th Annual Salmon Lecture, Auckland, 25 October 2012).

3 Whata (n 2) [8].

4 Whata (n 2) [20].

5 Whata (n 2) [85]. 
IUCN Academy of Environmental Law $14^{\text {th }}$ Colloquium University of Oslo Norway 20-25 June 2016

Previously, Dinah Shelton observed from an international perspective that human rights and the environment differ from other legal approaches to resource management because they emphasise "each individual's right to a certain quality of environment". ${ }^{6}$ She noted that human rights law has distinct advantages in relation to environmental protection, namely, that human rights are "maximum claims on society" and clearly distinguishable from "mere policy choice", and that constitutional guarantees will normally override other conflicting laws. Balanced against these "compelling" advantages are the disadvantages of a human rights approach to environmental protection, such as the anthropocentric focus on civil and political rights. ${ }^{7}$ Overall, she recognised that "a rights based approach" may radically affect how currently intractable issues are resolved, and she concluded that environmental rights must "include substantive ... standards" in order to be effective. ${ }^{8}$ She noted that:

Human rights exist to promote and protect human wellbeing, to allow the full development of each person and the maximization of the person's goals and interests, individually and in community with others. This cannot occur without safe environmental milieu, ie air, water, and soil. Pollution destroys life and health and thus not only destroys the environment, but infringes human rights as well.

These comments provide an insight into how currently intractable issues under the RMA (e.g. biodiversity protection on private land or competition for freshwater allocation) could be resolved. As noted by Whata, the statutory purpose in $s 5$ of the RMA provides for the promotion of the sustainable management of natural and physical resources. However, Malcolm Grant found that sustainable management is polycentric and that decision-making requires "tradeoffs" to be made. In particular, he observed that unless these choices are made via the RMA subsidiary policy statement and plan hierarchy

6 Dinah Shelton "Human rights and the environment" in Trevor DayaWinterbottom (ed) The Salmon Lectures - Justice and the Environment (2nd edn, Thomson Reuters, Wellington, 2012) 6-7.

7 Shelton (n 6) 34-59.

8 Shelton (n 6) 47. 
IUCN Academy of Environmental Law $14^{\text {th }}$ Colloquium University of Oslo Norway 20-25 June 2016

envisaged by the statutory architecture, sustainable management does not operate as a guiding ethic. ${ }^{9}$ For example, in North Shore City Council v Auckland Regional Council, ${ }^{10}$ the Environment Court adopted an "overall broad judgment" approach to resolve conflicting considerations that has been consistently applied in subsequent cases, holding that: ${ }^{11}$

The method of applying $s$ then involves an overall broad judgment of whether a proposal would promote the sustainable management of natural and physical resources. That recognises that the Act has a single purpose ... Such a judgment allows for comparison of conflicting considerations and the scale or degree of them, and their relative significance or proportion in the final outcome.

Effectively, absent any guidance from policy statements or plans the impact of the statutory purpose is "neutral", ${ }^{12}$ and decision-makers are left free to make a "value judgment on behalf of the community". ${ }^{13}$

While the RMA provides a non-exclusive list of matters in s 6 and s 7 that decision-makers are required to have regard to as examples of what may constitute sustainable management in particular cases, it is for note that these provisions are not expressly aligned with principles of international environmental law (e.g. protecting the habitat of exotic fish species such as trout and salmon) and that they were originally conceived by the Resource Management Law Reform process as an initial statement of matters of national policy. ${ }^{14}$ Arguably, this

9 Malcolm Grant "Sustainable management: A sustainable ethic?" in Trevor Daya-Winterbottom (ed) Frontiers of Resource Management Law (Thomson Reuters, Wellington, 2012) 47.

10 [1997] NZRMA 59.

11 [1997] NZRMA 59 at 94.

12 David Grinlinton "Contemporary Environmental Law in New Zealand" in Klaus Bosselmann and David Grinlinton (eds) Environmental Law for a Sustainable Society (New Zealand Centre for Environmental Law, Auckland, 2002) 26-27.

13 Watercare Services Ltd v Minhinnick [1998] NZRMA 113 (CA) at 124-125 per Tipping J.

14 Ministry for the Environment People, Environment, and Decision Making: the Government's Proposals for Resource Management Law Reform 
IUCN Academy of Environmental Law $14^{\text {th }}$ Colloquium University of Oslo Norway 20-25 June 2016

compounds the problem for decision-makers in terms of how they should approach exercising their wide discretion under the RMA.

\section{INTERNATIONAL ENVIRONMENTAL RIGHTS}

This section analyses the role of international environmental rights, for example, the right to a clean environment and the right to participate in environmental decision-making, in promoting the sustainable management of natural and physical resources.

\section{Right to a clean environment}

Some commentators have noted that cautious progress has been made toward establishing "an international human right to a clean environment". ${ }^{15}$ There are also parallels between the development of human rights law and environmental law in international human rights instruments. For example, the Charter of the United Nations does not expressly "provide any support for the idea that a clean or healthy environment should ... form part of those rights". ${ }^{16}$ Nevertheless, such rights have been developed by subsequent United Nations declarations and treaties. For example, Principle 1 of the Declaration of the United Nations Conference on the Human Environment (Stockholm Declaration) 1972 states that:

Man has the fundamental right to freedom, equality and adequate conditions of life, in an environment of a quality that permits a life of dignity and well-being, and he bears a solemn responsibility to protect and improve the environment for present and future generations.

From a New Zealand perspective, Susan Glazebrook argued for a right to environmental quality. She found that procedural environmental

(Ministry for the Environment, Wellington, 1988) 19; Philippe Sands and others Principles of International Environmental Law (3rd ed, Cambridge University Press, Cambridge, 2012) 187-237.

15 Malcolm N Shaw International Law (6th ed, Cambridge University Press, Cambridge, 2008) at 847-848

16 Philippe Sands and others Principles of International Environmental Law (3rd ed, Cambridge University Press, Cambridge, 2012) 777. 
IUCN Academy of Environmental Law $14^{\text {th }}$ Colloquium University of Oslo Norway 20-25 June 2016

rights "enjoy greater support than substantive rights", ${ }^{17}$ and noted that they are firmly based on civil and political rights and recognised constitutionally in a number of states. In contrast, Glazebrook observed that substantive rights to environmental quality are more closely related to economic and social rights, and that this may pose problems "in relation to the justiciability of these rights". ${ }^{18}$ While carefully considering arguments against a substantive right to environmental quality, such as, the need to avoid a proliferation of rights and general difficulties about characterising this right, she relied on the opinion of Judge Weeramantry in the River Danube case where he concluded that environmental quality is the foundation for basic human rights, holding that it was: ${ }^{19}$

... a vital part of contemporary human rights doctrine, for it is the sine qua non for the numerous human rights such as the right to health and the right to life itself. It is scarcely necessary to elaborate on this, as damage to the environment can impair and undermine all the human rights spoken of in the Universal Declaration and other human rights instruments.

Overall, Glazebrook (like Shelton) considered that there is a critical need to link procedural environmental rights with substantive rights to environmental quality to make them fully effective. For example, she noted that procedural rights are "not sufficient" alone to guarantee environmental quality, and that failure to provide procedural rights inhibits "the ability to enjoy ... substantive rights". ${ }^{20}$ In particular, Glazebrook noted the close "cultural and spiritual" relationship between indigenous people and their land and other natural resources, and

17 Susan Glazebrook "Human rights and the environment" in Paul Martin and others (eds) The Search for Environmental Justice (Edward Elgar, Cheltenham 2015) 86.

18 Glazebrook (n 17) 87.

19 Case concerning the Gabcikovo-Nagymaros Project (Hungary $v$ Slovakia) [1997] IC] Rep 7, separate opinion of Vice-President Weeramantry at 9192.

20 Glazebrook (n 17) 92; Shelton (n 6) 34-59. 
IUCN Academy of Environmental Law $14^{\text {th }}$ Colloquium University of Oslo Norway 20-25 June 2016

found that ownership and responsibilities tend to be communal. This led her to observe that: ${ }^{21}$

A healthy environment is intrinsically linked to the collective well-being of the people and traditional customs and customary laws are created in harmony with environmental sustainability.

As a consequence, Glazebrook considered that a right to environmental quality "can be seen as quintessentially an indigenous right". ${ }^{22}$ This led her to conclude that a right to environmental quality should be based on concept of guardianship that embraces intergenerational equity, and that it should be "separated" from substainable development "to ensure that human activity does not surpass the planet's limited resources". ${ }^{23}$

Philippe Sands also noted the distinction between the substantive nature of economic, social and cultural rights in setting environmental standards, and the procedural nature of civil and political rights in providing (inter alia) for information rights and "access to judicial or administrative remedies". ${ }^{24}$ He observed that "economic and social rights have traditionally been less well developed in practice", ${ }^{25}$ but noted the creative approach by the courts to enforce "substantive environmental rights". ${ }^{26}$

For example, the European Convention on Human Rights 1950 (ECHR) imposes a positive obligation on states in the context of the right to life (art 2) to provide an "effective system" of regulating, supervising and controlling the adverse effects of "inherently dangerous" activities that pose a risk to human life, such as "toxic emissions" from industrial activities, or the management of "waste disposal sites". ${ }^{27}$ However, art

${ }^{21}$ Glazebrook (n 17) 95.

22 Glazebrook (n 17) 95.

23 Glazebrook (n 17) 100.

24 Sands (n 16) 780.

25 Sands (n 16) 780

26 Sands (n 16) 782-785.

27 Guerra v Italy (1998) 27 EHRR 212; Oneryildiz v Turkey (2005) 41 EHRR 325; Clare Ovey and Robin CA White Jacobs and White The European 
IUCN Academy of Environmental Law $14^{\text {th }}$ Colloquium University of Oslo Norway 20-25 June 2016

8 of the ECHR regarding the right to respect for private and family life has generally been used as the basis for substantive environmental rights. For example, art 8 has been successfully pleaded in relation to the unlawful waste management activities, and where affected persons were not given access to environmental information concerning a proposed chemical factory in a timely way. ${ }^{28}$ In contrast, complaints regarding noise from night flights at Heathrow Airport were not upheld. ${ }^{29}$ In those cases, the Grand Chamber of the European Court of Human Rights focused on whether the activities were lawful, whether there was any non-compliance with regulations, whether the proposed activity had been "tested" and found to be "compatible" with statutory requirements, and whether the activities were in the "interests" of the national economy. ${ }^{30}$ The Court declined to "accord" any "special status" to environmental rights, and focused on the need for proof of: ${ }^{31}$

... the existence of a harmful effect on a person's private or family sphere and not simply on the general deterioration of the environment.

Overall, these cases demonstrate that the Court will have "regard to the balance of competing interests" when deciding whether the relevant regulatory authorities "have overstepped their margin of appreciation" that affords a degree of pragmatic deference to the need for efficient regulation in the modern state. ${ }^{32}$

In contrast with art 2 of the ECHR, s 8 of the New Zealand Bill of Rights Act 1990 (NZBORA) provides for the right not to be deprived of life. Thus unlike art 2, s 8 does not expressly contain any positive obligation to protect life such as economic and social rights to "an adequate standard of living" or a clean environment. Notwithstanding

Convention on Human Rights ( $4^{\text {th }}$ ed Oxford University Press, Oxford, 2006) 64.

28 Lopez Ostra v Spain (1995) 20 EHRR 277; Guerra (n 27).

29 Powell and Rayner $v$ United Kingdom (1990) 12 EHRR 355; Hatton $v$ United Kingdom (2003) 37 EHRR 611.

30 Ovey and White (n 27) 286.

31 Kyrtatos v Greece (2005) 40 EHRR 390, para 52.

32 Ovey and White (n 27) 52-54. 
IUCN Academy of Environmental Law $14^{\text {th }}$ Colloquium University of Oslo Norway 20-25 June 2016

more expansive interpretation of art 6 of the International Covenant on Civil and Political Rights 1966 (ICCPR) on which the NZBORA is based, leading academic commentary has rejected any positive interpretation of $\mathrm{s} 8$ because: ${ }^{33}$

- Generating "broad positive duties" would be "unworkable", open the flood gates to claims where the government failed to act, and require the courts to determine "non-justiciable controversies" regarding public policy and expenditure;

- The NZBORA applies to all branches of government including the judiciary and public authorities, who should not be "placed under a free-standing" and "expansive" duty; and

- The "idea" of positive obligations has been "firmly rejected" by the courts in the context of other "liberty rights" (i.e. thought, conscience and religious belief). ${ }^{34}$

Expectations regarding privacy and property rights are governed by $\mathrm{s}$ 21 of the NZBORA that prohibits unreasonable search or seizure. While the courts have been prepared to accept that "privacy" extends beyond "mere protection of property" (e.g. trespass) to include both individual or personal privacy and privacy regarding information, ${ }^{35}$ commentary on the NZBORA has also rejected any extension of the right against unreasonable seizure "divorced from a criminal justice orientation" to provide "a general guarantee of property rights". ${ }^{36}$ As a result, s 21 of the NZBORA is considerably narrower than the corresponding ECHR rights noted above, both in terms of the text and its current interpretation. Beyond that, the courts have found that individual assertions regarding "reasonable expectations of privacy" should be

33 Paul Rishworth and others, The New Zealand Bill of Rights (Oxford University Press, Melbourne, Australia, 2003) 222.

34 Mendelssohn v Attorney-General [1999] 2 NZLR 268 (CA) at 273; NZBORA, ss 13 and 15 .

$35 R v$ Jefferies [1994] 1 NZLR 290 (CA); Rishworth 421.

36 Rishworth (n 33) 430. 
IUCN Academy of Environmental Law $14^{\text {th }}$ Colloquium University of Oslo Norway 20-25 June 2016

determined objectively by measuring them "against the values held 'by the community at large'", ${ }^{37}$

Environmental decision-making has also intersected with the human rights and fundamental freedoms affirmed and protected by the NZBORA in 39 cases, including 7 cases focused on freedom of expression. For example, in Zdrahal $v$ Wellington City Council, ${ }^{38}$ an abatement notice was served to require the removal of swastikas painted on the outside of a house, and the Environment Court applied the objective standard of the ordinary "reasonable person", as the representative of the community, to determine whether they were "offensive and objectionable" under s 322 of the RMA. In doing so, the Court rejected an appeal based on s 14 of NZBORA, and held that protection of the environment and avoiding adverse effects warranted overriding the freedom to express beliefs and opinions that are offensive and objectionable and adversely affect the community. The Court found that imposing this restriction on these rights was reasonable and demonstrably justified.

\section{Right to participate in environmental decision-making}

Patricia Birnie and Alan Boyle, on the other hand, noted that "environmental rights do not fit neatly into any single category ... of human rights", but rather create an "enhanced status [for] environmental quality when balanced against competing objectives and other human rights, including the right to property". They identified three countervailing arguments against establishing a human rights approach to the environment, namely, the uncertainty surrounding the "qualitative" definition of the rights, the potential for an anthropocentric focus that does not respect the intrinsic value of ecological services or biodiversity, and the possibility that any new rights could be "redundant" and "add little to what already exists in

\footnotetext{
$37 R \vee$ Grayson and Taylor [1997] 1 NZLR 399 (CA) at 407; Rishworth (n 33) 421.

38 [1995] 1 NZLR 700.
} 
IUCN Academy of Environmental Law $14^{\text {th }}$ Colloquium University of Oslo Norway 20-25 June 2016

international law". ${ }^{39}$ However, they also noted relevant court decisions and observed that these could be seen as "a guarantee of effective remedies". ${ }^{40}$ Overall, Birnie and Boyle considered that procedural rights provided the "strongest" argument for a right to a clean environment enabling: 41

... individuals and NGOs to enforce domestic environmental law and ... help them shape domestic environmental policy ... public interest litigation may also diminish problems of anthropocentricity to the extent that rights can be exercised on behalf of the environment or of its nonhuman components, and not solely for human benefit. They can also be employed in the interests of future generations. A further advantage of such litigation is that it can serve as a means of making public bodies accountable for their action under international law.

In the New Zealand context, the right to participate in environmental decision-making has also been underscored by the Supreme Court in Discount Brands Ltd $v$ Westfield (New Zealand) Ltd, where Elias CJ observed that a "decision not to notify an application is an exception to the general policy of the Act that better substantive decision-making results from public participation", and Keith J emphasized the courts "gatekeeping" role where access to justice under s 27 of the NZBORA in engaged and requires "anxious" scrutiny of local authority decisions on judicial review. ${ }^{42}$

\section{PROPERTY RIGHTS}

This section analyses the role of property rights, for example, quiet enjoyment, in promoting the sustainable management of natural and physical resources.

\section{Quiet enjoyment}

39 Patricia Birnie and Alan Boyle International Law \& the Environment (2nd ed, Oxford University Press, New York, 2002) 256-259.

40 Birnie and Boyle 260; MC Mehta $v$ Union of India (1997) 2 SCC 353; Lopez Ostra (n 28); Guerra (n 27); Powell and Rayner (n 29).

41 Birnie and Boyle (n 39) 264.

42 [2005] NZSC 17 at [25] and [54]. 
IUCN Academy of Environmental Law $14^{\text {th }}$ Colloquium University of Oslo Norway 20-25 June 2016

The European Court of Human Rights has also considered nuisance complaints "caused by adjacent commercial activity" in the context of the protection of property under art 1 of the First Protocol to the $\mathrm{ECHR}^{43}$ that guarantees "peaceful enjoyment" of property and safeguards against compulsory acquisition otherwise than in accordance with due process, subject to the general ability of the state to regulate in the public interest. While the Court has held that land use controls imposed under planning restrictions "constitute measures of control on the use of property" caught by art $1,{ }^{44}$ it has nevertheless found such controls to be "permissible" when imposed by regulations that are demonstrated to be necessary and in the public interest. ${ }^{45}$ Generally, art 1 requires that "a fair balance" should be struck "between the individual interest and the general interest", ${ }^{46}$ which implies "a reasonable relationship of proportionality between the means employed and the aim pursued" while affording "a wide margin of appreciation" for the state in terms of selecting regulatory methods. ${ }^{47}$ The New Zealand courts have adopted a similar approach when balancing the rights affirmed and protected by the NZBORA. ${ }^{48}$

Beyond that, there is a strong New Zealand tradition of neo-liberal academic literature based on the US takings doctrine advocating for the constitutional recognition of property rights. ${ }^{49}$ These arguments have not found traction with the courts, ${ }^{50}$ but this appears to be more of a reaction against neo-liberal theory than an unwillingness to apply

\footnotetext{
43 Ovey and White (n 27) 284.

44 Pine Valley Developments Ltd v Ireland (1992) 14 EHRR 319; Clare Ovey and Robin CA White 371.

45 Ovey and White (n 27) 373.

46 Ovey and White (n 27) 372.

47 Chassagnou v France (2000) 29 EHRR 615, para 75.

48 Moonen v Film and Literature Board of Review [2000] 2 NZLR 9 (CA).

49 Philip A Joseph "Property rights and environmental regulation" in Trevor Daya-Winterbottom (ed) Frontiers of Resource Management Law (Thomson Reuters, Wellington, 2012) 124-143; Suri Ratnapala "Environmentalism Versus Constitutionalism: A Contest Without Winners" [2007] RM Theory \& Practice 110.

50 Waitakere City Council v Estate Homes Ltd [2006] NZSC 112.
} 
IUCN Academy of Environmental Law $14^{\text {th }}$ Colloquium University of Oslo Norway 20-25 June 2016

property law concepts (for example, non-derogation from grant) in an environmental law context. ${ }^{51}$

Richard Epstein, however, provided a valuable insight regarding the US takings doctrine, namely, that under both the US and New Zealand legal systems compensation is generally payable where "the government occupies somebody's land and takes it for public use", and that where regulation "merely restricts the use of land" compensation will generally not be payable. ${ }^{52}$ Focusing on land use regulation, he also found that both legal systems recognize that some relief should be provided where land use restrictions "deprive" the owner "of all economically viable use" - for example, under s 85(3) of the RMA the Environment Court has the power to direct local authorities to delete or replace any proposed district rules that would have such an effect. ${ }^{53}$ Beyond that, Epstein also noted that while land use restrictions can "disrupt" and "distort" the market, regulators will not be immune from public opinion "as their inefficiencies can lead to political backlash". ${ }^{54}$ For example, the Far North District Council adopted a prescriptive approach by mapping significant natural areas on private land (approximately 17 per cent of the district) and notified proposed rules that proscribed felling indigenous forest trees on the affected properties without resource consent. The failure of the district council to address concerns expressed by submitters regarding the quality of the data used for mapping, and misconceptions about the nature of property rights ultimately led to the proposed plan being withdrawn in 1998 two years after notification. ${ }^{55}$

Separately, Eduardo Peñalver focused on the "complexity of land" in his critique of the "traditional law and economics discussions of the

\footnotetext{
51 Hampton v Canterbury Regional Council [2016] NZSC 30.

52 Richard A Epstein Natural Resource Law \& Property Rights and Takings (New Zealand Business Roundtable, Wellington, 1999) 38.

53 Epstein (n 52) 38.

54 Epstein (n 52) 44.

55 Neil Ericksen and others Planning for Sustainability: New Zealand under the RMA (International Global Change Institute, University of Waikato, Hamilton, 2001).
} 
IUCN Academy of Environmental Law $14^{\text {th }}$ Colloquium University of Oslo Norway 20-25 June 2016

ownership of land". ${ }^{56}$ In particular, he observed that "land has memory" which affects our views about property and investment decisions through both perceptions about land use change (e.g. whether a particular site is used as a landfill or a church), and through historic settlement patterns that can remain in place long after any "locational advantages have been dissipated" and influence future development decisions. ${ }^{57}$ For example, Peñalver noted that: ${ }^{58}$

... sprawled out, low density residential neighborhoods built around automobile use and cheap gasoline will be extremely difficult to dislodge once fuel becomes expensive or the technology of personal transportation shifts away from the car.

There is, however, a convergence between these divergent views about property rights, in that most commentators generally agree that property rights are constitutionally important. For example, while Barry Barton considered that there is a legitimate role for land use regulation, he found that the power to regulate under the RMA is balanced by the protection offered to affected owners via the provision of submission, hearing, and appeal rights regarding proposed rules ${ }^{59}$ including their ability to challenge the rational basis for proposed rules under $\mathrm{s} 32$ or to seek that proposed rules should be deleted or replaced under $s$ 85. In particular, Barton categorized the protection offered by these provisions as being "constitutional" in nature, and considered that compensation should be payable where these participation rights are eroded by regressive simplifying and streamlining statutory amendments. ${ }^{60}$

Similarly, David Kirkpatrick noted that perverse results can occur where property rights are not properly understood, for example, where

56 Eduardo M Peñalver Land Virtues (Yale Legal Theory Workshop, New Haven, 2009) 1.

57 Peñalver (n 56) 10-12.

58 Peñalver (n 56) 12.

59 RMA, sch 1.

60 Barry Barton "The legitimacy of regulation" in Trevor Daya-Winterbottom (ed) Frontiers of Resource Management Law (Thomson Reuters, Wellington, 2012) 144-190. 
IUCN Academy of Environmental Law $14^{\text {th }}$ Colloquium University of Oslo Norway 20-25 June 2016

trees are felled before they reach the size where regulatory protection would apply. ${ }^{61}$ In particular, Kirkpatrick (based on the writings of Jeremy Waldron) was concerned that "exchange" and "income" rights are not fully recognized by local authorities when preparing district rules. $^{62}$ Likewise, Epstein also emphasized that the "bundle" of property rights recognized under English derived common law includes the ability to possess, use, and dispose of property. ${ }^{63}$

Other commentators have focused on the peculiar characteristics of natural resources (e.g. freshwater). For example, the moral philosopher, Mary Warnock, questioned whether absent concepts of common property we can feel the same responsibility for what we do not own, and suggested that only "Promethean fear" of adverse effects can promote responsibility for the environment. ${ }^{64}$ Whereas, Daniel Bromley, from a law and economics perspective considered that some form of ownership is the key to responsibility, while the type of ownership adopted (e.g. private or common) should reflect the values and traditions of the particular society promulgating the regulations. ${ }^{65}$ While Joseph Sax noted the need to define property-like entitlements in the context of permits for the take and use of freshwater - which remains a contentious issue in regions where freshwater bodies are nearing full allocation. ${ }^{66}$ In contrast, Danny Nicol argued that defining property as a human right could be described as the "fundamental right of the well-to-do" and perceived as an "insurance policy" to preserve neo-liberal policies. ${ }^{67}$ Beyond that, Eric Freyfogle

61 David Kirkpatrick "Property rights: Do you have any?" in Trevor DayaWinterbottom (ed) Frontiers of Resource Management Law (Thomson Reuters, Wellington, 2012) 93-123.

62 Kirkpatrick ( $\mathrm{n}$ 61) 96; Jeremy Waldron The Right to Private Property (Clarendon Press, Oxford, 1988).

63 Epstein (n 52) 41.

64 Mary Warnock Critical Reflections on Ownership (Edward Elgar Publishing, Cheltenham, 2015) 142.

65 Daniel W Bromley Property Rights and the Environment: Natural Resource Policy in Transition (Ministry for the Environment, Wellington, 1988).

66 Joseph L Sax "Our precious water resources: learning from the past, securing the future" [2009] RM Theory \& Practice 30.

67 Danny Nicol The Constitutional Protection of Capitalism (Hart Publishing, Oxford, 2010) 128-151. 
IUCN Academy of Environmental Law $14^{\text {th }}$ Colloquium University of Oslo Norway 20-25 June 2016

acknowledged the need for a proper understanding of property rights, but argued that property rights need to be redefined to reflect the societal shift implicit in the requirement to promote the sustainable management of natural and physical resources in an "ecologically sound" way. ${ }^{68}$

Separately, Alex Frame suggested that the property rights debate has provided the catalyst for developing New Zealand jurisprudence on property - liberating views about legal personality. ${ }^{69}$ This has arisen as a response to the commercialization or privatization of hydro electricity and other assets divested by the state during the period since 1984, and the resulting "commodification" of the natural and physical resources used by the new owners. ${ }^{70}$ For example, Frame observed that: ${ }^{71}$

Not surprisingly, the Maori reaction has been: if it is property, then it is our property!

Frame based his thesis on the analysis of the New Zealand jurist, John Salmond, who articulated a broad "conception of personality" that recognizes "persons who are not men". ${ }^{72}$ He then extended this concept to "geographical features" of significance to Maori (e.g. rivers and mountains) because they are "seen as tupuna" or ancestors, that he considered "do not lend themselves to allocation as property without engendering feelings of dispossession". ${ }^{73}$ This led Frame (inspired by Polynesian custom and the writings of Christopher Stone) to suggest that rivers and other geographic features could be given

68 Eric T Freyfogle "Taking Property Seriously" in David Grinlinton and Prue Taylor (eds) Property Rights and Sustainablity (Martinus Nijhoff Publishers, Leiden, 2011) 43-61.

69 Alex Frame "Property and the Treaty of Waitangi" in Janet McLean (ed) Property and the Constitution (Hart Publishing, Oxford, 1999) 236-238.

70 Frame (n 69) 234.

71 Frame (n 69) 234.

72 Frame (n 69) 236.

73 Frame (n 69) 237. 
IUCN Academy of Environmental Law $14^{\text {th }}$ Colloquium University of Oslo Norway 20-25 June 2016

legal personaility, with persons being appointed to speak on their behalf. $^{74}$

\section{CULTURAL RIGHTS}

This section analyses the role of cultural rights, for example, kaitiakitanga or the exercise of guardianship by Maori in accordance with customary values and practices in relation to natural and physical resources, in promoting sustainable management.

\section{Rule of law for nature}

Whata noted the strong ecological approach in New Zealand environmental law writing that "maintains" the normative value of sustainable management as an "ethic" that "should guide our actions" in a similar way to the influence of the concept of justice on the law generally. ${ }^{75}$ Internationally, Jordi Jaria i Manzano considered the "paradigm shift" achieved by the Ecuadorian constitution when incorporating the rights of nature. He noted that indigenous concepts providing for "good living" pervade the document, and that specific provision is made to respect nature (Pacha Mama - Mother Earth) and its reproductive, regenerative and evolutionary processes, and for the restoration of nature as part of the "constitutional obligations of Ecuadorian citizens". ${ }^{76}$ Manzano noted the arguments against expanding rights beyond humans to nature and giving nature legal personality, but considered that expanding constitutional rights in this way is consistent with Latin American traditions in legal philosophy and "using the constitution as a tool for social transformation". ${ }^{77}$ However, he criticised the methods used to incorporate the rights of nature in

\footnotetext{
74 Frame (n 69) 237.

75 Whata (n 2) [29]; Peter Salmon "Sustainable Development in New Zealand" in Trevor Daya-Winterbottom (ed) Justice and the Environment ( $1^{\text {st }}$ edn, Resource Management Law Association, Auckland, 2007) 19 and 21.

76 Jordi Jaria i Manzano "The rights of nature in Ecuador: and opportunity to reflect on society, law and environment" in Robert V Percival, Jolene Lin and William Piermattei (eds) Global Environmental Law at a Crossroads (Edward Elgar, Cheltenham 2014) 49-51.

77 Manzano (n 76) 53.
} 
IUCN Academy of Environmental Law $14^{\text {th }}$ Colloquium University of Oslo Norway 20-25 June 2016

the constitution because, by "humanising" nature, the constitutional provisions do not achieive the desired objective of protecting nature but, instead, reduce "nature to just one among many complex and competing interests thereby diminishing rather than raising its importance". ${ }^{78}$ Notwithstanding these concerns, Manzano considered that the positive effect of the Ecuadorian constitution is the cultural shift from a western to an indigenous world-view of nature: ${ }^{79}$

... because looking at non-Western cultures seems to be the best way of moving from a constitutionalism based on rights to a constitutionalism based on responsibilities; that is, from the (ab)use of nature to the respect and care for nature.

The New Zealand based academic, Joel Colón-Rios, also considered the rights to nature in the Ecuadorian constitution. He reflected on the case of the Vilcabamba River where spoil from new road works constructed by the provincial government was deposited in the river and protective action was taken by third parties, on behalf of the river, based on the rights to nature in art 71 of the constitution. The Provincial Court applied a reverse burden of proof, requiring the provincial government to prove that the road works had not caused any environmental harm. The plaintiffs succeeded, and the Court made orders for a remediation and rehabilitation plan to be prepared and gave directions about how the works should be completed. Notwithstanding the decision, the outcome of the case was not entirely successful as the remediation and rehabilition plan was not implemented. However, Colón-Rios observed that the real success of the case was that: ${ }^{80}$

... it opened an avenue that did not exist before, that is, it showed that the rights of nature are susceptible of judicial application in ordinary and local contexts.

78 Manzano (n 76) 57

79 Manzano (n 76) 62.

80 Joel I Colon-Rios "On the theory and practice of the rights of nature" in Paul Martin and others (eds) The Search for Environmental Justice (Edward Elgar, Cheltenham 2015) 130. 
IUCN Academy of Environmental Law $14^{\text {th }}$ Colloquium University of Oslo Norway 20-25 June 2016

Beyond that, Fisher also drew attention to the rights to nature in art 71 of the Ecuadorian constitution, and emphasized the power provided by this provision that enables any person to "call upon public authorities to enforce the rights of nature", together with the duty in art 83 of the constitution "to respect the rights of nature, preserve a healthy environment and use natural resources rationally, sustainably and durably". ${ }^{81}$ As a result, he found that "nature" has been given legal personality and imbued with rights, that are "capable" of enforcement via the combination of rights and duties in arts 71 and 83 of the constitution. ${ }^{82}$

\section{Guardianship}

Maori cultural values also intersect with resource management as a result of the settlement of indigenous grievances under the Treaty of Waitangi Act 1975. For example, the Waikato-Tainui Raupatu Claims (Waikato River) Settlement Act 2010 built on the Maori concept of kaitiakitanga by appointing guardians to prepare a vision and strategy for the river catchment, that articulates Maori customary values and practices and gives legal effect to them as part of the regional policy statement prepared under the RMA. In addition, the statute also provides for co-governance by providing Maori with a decision-making role together with the local authorities responsible for administering the RMA in the Waikato region. These developments are part of a trend that has emerged gradually since the 1970 s by applying the concept of guardianship initially to lakes and fiords, ${ }^{83}$ and more generally by establishing the office of the Parliamentary Commissioner for the Environment (PCE) as guardian for the New Zealand environment via the right to be heard in any proceedings concerning applications for environmental consents, and by affording special constitutional status

81 Douglas Fisher Legal Reasoning in Environmental Law (Edward Elger Publishing, Cheltenham, 2013) 282.

82 Fisher (n 81) 282.

83 Conservation Law Reform Act 1990; Fiordland (Te Moana o Atawhenua) Marine Management Act 2005. 
IUCN Academy of Environmental Law $14^{\text {th }}$ Colloquium University of Oslo Norway 20-25 June 2016

to the PCE as an officer of Parliament. ${ }^{84}$ The right to be heard in proceedings has not, however, been exercised to date.

More recently, the Maori concept of kaitiakitanga has been expanded further to provide for guardianship, co-governance and the transfer of legal title to the mountain ranges of the Te Urewera national park to Maori, and the recognition of the mountains as legal persons. ${ }^{85}$ Similarly, the Te Awa Tupua (Whanganui River Claims Settlement) Bill 2015, currently before select committee in Parliament, recognizes the river catchment as a legal person, imposes a duty on all persons to recognize and provide for the river and its associated values, and enables the river to have legal standing and an independent voice via two guardians who are to be appointed by the Crown and Maori to act on behalf of the river.

These development also build on the writings of Frame, Manzano, and Colon-Rios noted above, and could potentially provide the basis for expanding the concept of kaitiakitanga or guardianship even further as the foundation for indigenous earth governance (similar to the provisions in the Ecuadorian constitution) based on Papatuanuku, Mother Earth from Maori tikanga.

Additionally, Joseph Williams has also provided valuable insights regarding the fusion of the English based common law with Maori tikanga (customary values and practices) ${ }^{86}$ to create a distinctive New Zealand jurispridence in the spheres of both public and private law. ${ }^{87}$ For example, in Tamaki v Maori Women's Welfare League, the High

84 Environment Act 1986, s 4 and s 21; Gary Hawke (ed) Guardians for the Environment (Institure of Policy Studies, Wellington, 1997); David Young Keeper of the Long View: Sustainability and the PCE (Parliamentary Commissioner for the Environment, Wellington, 2007); Joseph 383-384 and 395-399.

85 Te Urewera Act 2014, s 11; Rachael Harris "A legal identity for Te Urewera: The changing face of co-governance in the central North Island" [2015] RM Theory \& Practice 148.

86 RMA, s 2(1).

87 Joseph Williams (presentation at Resource Management Law Association Annual Conference, Wellington, 1-3 October 2009), cited in "Editorial Introduction" [2010] RM Theory \& Practice 5. 
IUCN Academy of Environmental Law $14^{\text {th }}$ Colloquium University of Oslo Norway 20-25 June 2016

Court on judicial review found that "consistency with the wider values and practices of tikanga" was relevant in relation to decision-making by an incorporated society; ${ }^{88}$ and in Takamore $v$ Clarke, the Court of Appeal found that executors were subject to a broad "requirement to consider tikanga Maori and other important cultural, spiritual and religious values" when deciding where a deceased Maori person should be buried. ${ }^{89}$ Similarly, both Loughlin and Tipene O'Regan have noted that the foundations of English common law and Maori tikanga are based on custom, practical knowledge and experience. ${ }^{90}$ In particular, O'Regan advocated for a pragmatic view of Maori tikanga and observed that: ${ }^{91}$

In my view it is the capacity for dynamic adaptation which is the particular genius of Maori culture and associated values. I believe that this is powerfully demonstrated in Maori traditional history as well as in our more recent historical experience. I take the view that we should follow the historical precent of our tupuna and permit our values to flourish in accordance with the changing environment and the expansion of human knowledge and capacity.

Beyond that, Whata also considered that kaitiakitanga has a common law dimension. ${ }^{92}$ For example, he noted strong arguments for the proposition that the statutory purpose of sustainable management in $\mathrm{s}$ 5 of the RMA incorporates international norms, and that the duty to have regard to kaitiakitanga in $s 7(a)$ of the RMA infers that the exercise of guardianship arises independent of statute law as a customary environmental right. ${ }^{93}$

\section{RIGHTING ENVIRONMENTAL LAW}

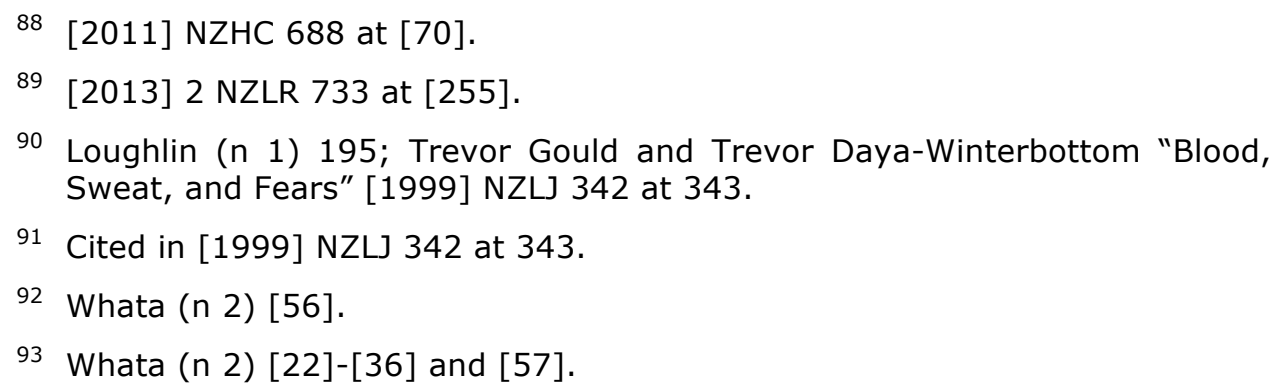


IUCN Academy of Environmental Law $14^{\text {th }}$ Colloquium University of Oslo Norway 20-25 June 2016

This section critically explores how a rights based approach to environmental conflict resolution could be implemented under New Zealand law to give effect to international environmental law principles.

\section{Constitionality and constitutional statutes}

May and Daly found that a combination of access to information, participation in decision-making and standing to pursue remedies are the cornerstone for achieving environmental protection. ${ }^{94}$ More critically, they argued that environmental procedural rights "can be severely curtailed" when provided for under national legislation, and expressed a clear preference for the constitutional guarantee of procedural rights. ${ }^{95}$ Providing such guarantees will therefore be problematic in states, such as New Zealand, that rely on an unwritten constitution.

Some commentators have sought to resolve this problem by classifying certain statutes as constitutional statutes. For example, Scott Stephenson and Rivka Weill defined constitutional statutes as laws that affect "a fundamental constitutional feature of a constitutional system" that are enacted via the ordinary law making process in a common law evolutionary fashion. ${ }^{96}$ In the New Zealand context, Philip Joseph has classified the Official Information Act 1982, the Human Rights Act 1993, and the Citizens Initiated Referenda Act 1993 as "pre-eminently constitutional" based on their objectives of ensuring access to information, promoting equality of opportunity and participatory

94 James R May and Erin Daly "The Future We Want and constitutionally enshrined procedural rights in environmental matters" in Robert V Percival, Jolene Lin and William Piermattei (eds) Global Environmental Law at a Crossroads (Edward Elgar, Cheltenham 2014) 47.

95 May and Daly (n 94) 37-38.

96 Scott Stephenson "Quasi-Constitutionality and the Question of Convergence" (paper presented to the Global Symposium on QuasiConstitutionality and Constitutional Statutes, Victoria University of Wellington, 19-20 May 2016) 2; Rivka Weill "Exploring Constitutional Statutes in Common Law Systems" (paper presented to the Global Symposium on Quasi-Constitutionality and Constitutional Statutes, Victoria University of Wellington, 19-20 May 2016). 
IUCN Academy of Environmental Law $14^{\text {th }}$ Colloquium University of Oslo Norway 20-25 June 2016

democracy. ${ }^{97}$ Similarly, Prue Taylor considered the role of the RMA as implementing legislation in relation to New Zealand's international environmental law obligations "that came into force prior to, and following, its 1991 enactment". ${ }^{98}$ Arguably, based on David Boyd's analysis of the general protection given to environmental rights by the majority of UN member states via constitutional provisions, domestic legislation, judicial decisions, and ratification of multi-lateral environmental agreements, ${ }^{99}$ the RMA is constitutionally significant.

Geoffrey Palmer also observed that "constitutionalising" environmental protection may provide a way of reconciling the tensions between conservation and development, ${ }^{100}$ and advocated for the adoption of a right to environmental quality enforced by directive statutes based on art 24 of the South African constitution. In particular, Palmer considered that South African case law on art 24 would provide valuable persuasive authority for interpreting environmental rights included in the proposed written constitution for New Zealand. ${ }^{101}$

For example, the impact of art 24 can be illustrated by reference to three cases. First, in Save the Vaal the transformative character of the constitution was observed by noting that it ushered in a new "ideological climate". ${ }^{102}$ Second, the BPSA decision recognized the

97 Philip A Joseph Constitutional and Administrative Law in New Zealand (4 ${ }^{\text {th }}$ edn, Thomson Reuters, Wellington, 2014) 265.

98 Prue Taylor "The relevance of International Environmental Law for Domestic Law" in Peter Salmon and David Grinlinton (eds) Environmental Law in New Zealand (Thomson Reuters, Wellington, 2015) 298; Ramsar Convention 1971; Convention on Biological Diversity 1992; Framework Convention on Climate Change 1992; Kyoto Protocol 1997.

99 David R Boyd, The Environmental Rights Revolution: A Global Study of Constitutions, Human Rights and the Environment (University of British Columbia Press, Vancouver, 2012).

${ }^{100}$ Geoffrey Palmer "The Resource Management Act Reforms: A return to Unbridled Power?" (paper presented to Environmental Defence Society Conference, Auckland, 7 August 2013) 12.

${ }^{101}$ Geoffrey Palmer and Andrew Butler A Consitution for Aotearoa New Zealand (Victoria University Press, Wellington, 2016) The proposed Constitution: the full text, A Note on Sources.

102 Director, Mineral Development $v$ Save the Vaal Environment (1999) Butterworths Constitutional Law Reports 8, 845 at para 20; Fisher (2013), 313. 
IUCN Academy of Environmental Law $14^{\text {th }}$ Colloquium University of Oslo Norway 20-25 June 2016

redundancy of purely economic approaches to development, and firmly adopted the requirement to "balance" ecological and economic and social needs. ${ }^{103}$ Third, the approach to statutory interpretation in Fuel Retailers recognized the constitutionality of legislation enacted to give effect to the environmental rights in art 24. ${ }^{104}$ However, while Douglas Fisher observed that these decisions emphasize the duty accepted by the courts "to uphold the constitution", ${ }^{105}$ the prevailing view of other commentators is that art 24 of the South African constitution has had no real impact on shaping legal rules - because the Constitutional Court has failed to clarify sufficiently the scope and content of the environmental rights, and because there has been insufficient litigation as a result. ${ }^{106}$

The impact of litigation on developing jurisprudence is important. For example, Palmer stressed the importance of litigation in relation to the statutory purpose of promoting sustainable management in $s$ of the RMA when he observed that: ${ }^{107}$

Once an appropriate case reaches the New Zealand Court of Appeal, it can confidently be predicted that a suitably progressive yet workable approach will be taken to the Act. The Court has a sound record on environmental issues. It has increasingly shown itself to be capable of dealing effectively with the challenge of crafting broad principle into workable judicial tests, a task at which it has excelled in the cases under the New Zealand Bill of Rights Act 1990.

${ }^{103}$ BPSA (Pty) Ltd v Minister (2004) South Africa 2004 (5) 124 at 144; Fisher (2013), 314.

${ }^{104}$ Fuel Retailers Association of South Africa $v$ Director-General Environmental Management, Department of Agriculture, Conservation and Management (2007) Butterworths Constitutional Law Reports 10, 1059 at para 40; Fisher (2013), 315.

${ }^{105}$ Fisher (n 81) 319.

${ }^{106}$ Lael K Weis "Understanding the Constitutional Function of Directive Principles: The Role of Directive Legislation" (paper presented to the Global Symposium on Quasi-Constitutionality and Constitutional Statutes, Victoria University of Wellington, 19-20 May 2016) 14; Michael Kidd "Public Interest Environmental Litigation: Recent Cases Raise Possible Obstacles" (2010) 13 Potchefstroom Elec LJ 27.

107 Geoffrey Palmer Environment: The International Challenge (Victoria University Press, Wellington, 1995) 173. 
IUCN Academy of Environmental Law $14^{\text {th }}$ Colloquium University of Oslo Norway 20-25 June 2016

But notwithstanding this confidence, only three significant cases have to date been decided by the courts regarding the approach to sustainable management under the RMA. ${ }^{108}$

Additionally, Lael Weis drew attention to the right to property in art 25 of the South African constitution in terms of the workability of the environmental rights in art 24, ${ }^{109}$ and both Fisher and Weis drew attention to "interpretive" provisions in art 39 that impose obligations to promote constitutional values and require other laws to be applied in a consistent way - raising the spectre of declarations of inconsistency. ${ }^{110}$ Most recently, in the New Zealand context in Taylor $v$ Attorney-General Heath J held that the High Court has jurisdiction to make a declaration of inconsistency, notwithstanding the fact that NZBORA is not supreme law, and stated that: ${ }^{111}$

... I take the view that the existence of this legislation manifests an acceptance by Parliament that a judicial tribunal can appropriately state, in a formal way, that legislation passed by it is inconsistent with a right affirmed or guaranteed by the Bill of Rights.

This is a significant common law development, particularly when read together with the environmental rights in art 105 of the proposed written constitution for New Zealand. ${ }^{112}$

\section{Common laws of the environment}

From a New Zealand perspective, Sian Elias placed environmental law in its wider legal context, in particular its role as "a branch of administrative law". ${ }^{113}$ Recognising the need for the law to balance

${ }^{108}$ North Shore City Council v Auckland Regional Council [1997] NZRMA 59 (NZEnvC); Watercare Services Ltd v Minhinnick [1998] 1 NZLR 294 (NZCA); Environmental Defence Society Inc $v$ The New Zealand King Salmon Company Ltd [2014] NZSC 38.

${ }^{109}$ Weis (n 106) 15.

${ }^{110}$ Fisher (n 81) 313.

${ }^{111}$ Taylor v Attorney-General [2015] NZHC 1706 at [6], [66], and [73].

112 Palmer and Butler (n 101).

${ }^{113}$ Sian Elias "Righting Environmental Justice" (12th Annual Salmon Lecture, Auckland, 25 July 2013) at 2. 
IUCN Academy of Environmental Law $14^{\text {th }}$ Colloquium University of Oslo Norway 20-25 June 2016

competing demands for procedural fairness, democratic participation, and an evidence-based approach to decision-making firmly grounded on good science, ${ }^{114}$ she noted the constitutional advancements made in providing for access to information, establishing the office of the Ombudsmen to underpin "good administration", and the importance accorded to access to justice from a human rights perspective. She observed that: ${ }^{115}$

People want to know why decisions are taken by others exercising public powers which affect them. If they are given the dignity of reasons, they want them to justify the conclusion.

Expressing some "sympathy" for the suggestion "that the judiciary should not be placed in the position of having to determine values or policy", ${ }^{116}$ she noted that there are critical differences between human rights adjudication and environmental conflict resolution, as human rights are expressed in qualified terms that are underpinned by a sound theoretical basis and both "international and comparative jurisprudence": ${ }^{117}$

By contrast, environmental conflict is intrinsically much more difficult to resolve if the ends in view are not ordered in any way that provides a handle for decision-makers, as by setting minimum standards which do confer rights of enforcement. At-large judicial balancing may be at best unconvincing and at the worst may mask political judgments which cannot be adequately justified by reference to legal standards and which should be directly taken by those who are politically accountable.

Previously, Elias emphasized the need for "organizing principles" while noting the inherent constraints of the common law in developing "statements of over-arching principle" from the mass of case law generated by pragmatic and sporadic litigation. She also noted the

${ }^{114}$ Elias (n 113) 2-3, referring to Robin Cooke "Forward" in Kenneth Palmer Planning and Development Law in New Zealand (2nd ed, Law Book Company, Sydney, 1984).

${ }^{115}$ Elias (n 113) 5.

${ }_{116}$ Elias (n 113) 13.

${ }^{117}$ Elias (n 113) 15. 
IUCN Academy of Environmental Law $14^{\text {th }}$ Colloquium University of Oslo Norway 20-25 June 2016

dynamic nature of the common law, its organic development over time in parallel with "the history of the country and its people", and the need to discard principles that are no longer relevant - observing that: ${ }^{118}$

Legal method comprises discovering the principle that convinces, while providing certainty balanced with justice that moves with the times.

Subsequently, Elias emphasized the need for courts to create jurisprudence to guide future disputes. ${ }^{119}$ While Lord Carnwath mapped the general judicial response to "environmental challenges" and concluded that despite differing legal frameworks "many of ... their solutions are of universal application", ${ }^{120}$ and that:

The emerging principles can be seen as the foundation of a system of 'common laws of the environment'.

He drew particular attention to the decision in Telstra Corporation $v$ Hornsby Shire Council, ${ }^{121}$ where Chief Justice Brian Preston of the New South Wales Land and Environment Court outlined six basic principles, namely:

- Sustainable use;

- Integration of economic and environmental considerations;

- Precautionary principle;

- Equity (including inter-generational equity);

- Conservation of biological diversity;

- Internalization of environmental costs.

\footnotetext{
${ }^{118}$ Sian Elias "Foreword" in Rick Bigwood (ed) Legal Method in New Zealand (Butterworths, Wellington, 2001) vi.

${ }^{119}$ Cited in Environment Court of New Zealand Annual Review 2015 (Environment Court of New Zealand, Auckland, 2016) 29.

${ }^{120}$ MC Mehta $v$ Union of India [1998] 6 SC 63 (CNG buses); Oposa v Factoran GR No 101083 (SC 30 July 1993) (Phil) (Minors' case).

121 (2006) 146 LGERA 10.
} 
IUCN Academy of Environmental Law $14^{\text {th }}$ Colloquium University of Oslo Norway 20-25 June 2016

This led Lord Carnwath to observe that:

Although derived from the interpretation of local legislation, these principles are of much wider application and can be found in other jurisdictions in both law and policy.

For example, Ceri Warnock and Nicola Wheen surveyed the suite of New Zealand environmental law statutes and arrived at a similar conclusion to Preston $\mathrm{CJ} .{ }^{122}$ They identified the following principles: sustainable development, the precautionary principle, the polluter pays principle, Treaty of Waitangi principles regarding indigenous rights, and procedural rights. While David Sheppard identified, sustainable management, administrative justice, proportionality, and equity (including "siting equity" that seeks to avoid locating hazardous activities in economically disadvantaged areas) as "fundamental" principles in the specific RMA context. ${ }^{123}$

Most recently, in Environmental Defence Society Inc $v$ The New Zealand King Salmon Co Ltd, ${ }^{124}$ the Supreme Court was given the opportunity to consider the RMA statutory purpose in $s 5$. The Court adopted an ecological approach to sustainable management, and found that policy statements and plans can include provisions that are directive in nature that must be complied with when lower-level instruments are prepared or when resource consent applications are decided. In doing so, the Court sanctioned the use of non-negotiable environmental bottom lines that require adverse effects on the environment to be avoided. But more importantly, the Court

122 Ceri Warnock and Nicola Wheen "Introduction" in Brookers Environmental Legislation Handbook (Thomson Reuters, Wellington, 2014) 6-12; Biosecurity Act 1993; Climate Change Response Act 2002; Conservation Act 1987; Crown Minerals Act 1991; Environment Act 1986; Exclusive Economic Zone and Continental Shelf (Environmental Effects) Act 2012; Fisheries Act 1996; Hazardous Substances and New Organisms Act 1996; Marine Mammals Protection Act 1978; Marine Reserves Act 1971; Ngai Tahu Claims Settlement Act 1996; Subantartic Islands Marine Reserves Act 2014; Waikato-Tainui Raupatu Claims (Waikato River) Settlement Act 2010; Wildlife Act 1953.

${ }^{123}$ David Sheppard "The Resource Management Act - from principles to practice" in Trevor Daya-Winterbottom (ed) Frontiers of Resource Management Law (Thomson Reuters, Wellington, 2012) at 225.

124 [2014] NZSC 38. 
IUCN Academy of Environmental Law $14^{\text {th }}$ Colloquium University of Oslo Norway 20-25 June 2016

determined that where "directive" provisions are included in policy statements or plans, applying an overall broad judgment approach will not be appropriate.

Beyond that, Gitanjali Gill suggested that public interest litigation (such as King Salmon) is part of the journey towards ensuring that environmental law is effective. ${ }^{125}$ For example, the Environmental Defence Society has played a critical role in the development of New Zealand law. For example, Environmental Defence Society Inc $v$ South Pacific Aluminium (No 3$)^{126}$ followed the leading English decision in $R v$ Inland Revenue Commissioners, ex parte National Federation of SelfEmployed and Small Businesses $L t d{ }^{127}$ by providing a "flexible" and "generous" approach to standing in public law cases and it is now axiomatic that: ${ }^{128}$

... responsible public interest groups representing a relevant aspect of the public interest have a strong case for standing where the decision can be expected to have community impact, as in resource management cases.

Overall, rights based approaches arguably provide "a more focused, consistent and transparent methodology". ${ }^{129}$

\section{CONCLUSIONS}

Rights based approaches to environmental law may radically affect how issues are resolved by:

\footnotetext{
${ }^{125}$ Gitanjali Gill "Human rights and environmental protection in India: the judicial journey from public interest litigation to the National Green Tribunal" in Anna Grear and Evadne Grant (eds) Thought, Law, Rights and Action in the Age of Environmental Crisis (Edward Elgar Publishing, Cheltenham, 2015) 123.

${ }^{126}$ [1981] 1 NZLR 216 (CA).

${ }^{127}$ [1982] AC $617(\mathrm{HL})$.

${ }^{128}$ Rick Bigwood Public Interest Litigation (LexisNexis, Wellington, 2006) 85; Moxon v Casino Control Authority HC Hamilton M324/99 \& M325/99 24 May 2000 at [105].

${ }^{129}$ Michael Taggart "Reinventing Administrative Law" in Nicholas Bamforth and Peter Leyland (eds) Public Law in a Multi-Layered Constitution (Hart Publishing, Oxford, 2003) 326.
} 
IUCN Academy of Environmental Law $14^{\text {th }}$ Colloquium University of Oslo Norway 20-25 June 2016

- Applying objective legal standards, such as proportionality or the "reasonable person", to assist with balancing rights.

- Setting threshold standards to provide a handle for decisionmakers - that make it explicit when adverse effects are to be avoided.

- Adopting an evidence-based approach to decision-making firmly based on good science (including social science).

- Providing for rights to be exercised on behalf of the environment via public interest litigation as a fail-safe to ensure effective implementation.

\section{References}

Barry Barton "The legitimacy of regulation" in Trevor Daya-Winterbottom (ed) Frontiers of Resource Management Law (Thomson Reuters, Wellington, 2012).

Rick Bigwood Public Interest Litigation (LexisNexis, Wellington, 2006).

Patricia Birnie and Alan Boyle International Law \& the Environment (2nd ed, Oxford University Press, New York, 2002).

David R Boyd, The Environmental Rights Revolution: A Global Study of Constitutions, Human Rights and the Environment (University of British Columbia Press, Vancouver, 2012).

Daniel W Bromley Property Rights and the Environment: Natural Resource Policy in Transition (Ministry for the Environment, Wellington, 1988).

Joel I Colon-Rios "On the theory and practice of the rights of nature" in Paul Martin and others (eds) The Search for Environmental Justice (Edward Elgar, Cheltenham 2015).

Sian Elias "Foreword" in Rick Bigwood (ed) Legal Method in New Zealand (Butterworths, Wellington, 2001). 
IUCN Academy of Environmental Law $14^{\text {th }}$ Colloquium University of Oslo Norway 20-25 June 2016

Sian Elias "Righting Environmental Justice" (12th Annual Salmon Lecture, Auckland, 25 July 2013).

Richard A Epstein Natural Resource Law \& Property Rights and Takings (New Zealand Business Roundtable, Wellington, 1999).

Neil Ericksen and others Planning for Sustainability: New Zealand under the RMA (International Global Change Institute, University of Waikato, Hamilton, 2001).

Douglas Fisher Legal Reasoning in Environmental Law (Edward Elger Publishing, Cheltenham, 2013).

Alex Frame "Property and the Treaty of Waitangi" in Janet McLean (ed) Property and the Constitution (Hart Publishing, Oxford, 1999).

Eric T Freyfogle "Taking Property Seriously" in David Grinlinton and Prue Taylor (eds) Property Rights and Sustainablity (Martinus Nijhoff Publishers, Leiden, 2011).

Gitanjali Gill "Human rights and environmental protection in India: the judicial journey from public interest litigation to the National Green Tribunal" in Anna Grear and Evadne Grant (eds) Thought, Law, Rights and Action in the Age of Environmental Crisis (Edward Elgar Publishing, Cheltenham, 2015).

Susan Glazebrook "Human rights and the environment" in Paul Martin and others (eds) The Search for Environmental Justice (Edward Elgar, Cheltenham 2015).

Trevor Gould and Trevor Daya-Winterbottom "Blood, Sweat, and Fears" [1999] NZLJ 342.

David Grinlinton "Contemporary Environmental Law in New Zealand" in Klaus Bosselmann and Dadiv Grinlinton (eds) Environmental Law for a Sustainable Society (New Zealand Centre for Environmental Law, Auckland, 2002).

Gary Hawke (ed) Guardians for the Environment (Institure of Policy Studies, Wellington, 1997). 
IUCN Academy of Environmental Law $14^{\text {th }}$ Colloquium University of Oslo Norway 20-25 June 2016

Philip A Joseph "Property rights and environmental regulation" in Trevor DayaWinterbottom (ed) Frontiers of Resource Management Law (Thomson Reuters, Wellington, 2012).

Philip A Joseph Constitutional and Administrative Law in New Zealand $\left(4^{\text {th }}\right.$ edn, Thomson Reuters, Wellington, 2014).

Michael Kidd "Public Interest Environmental Litigation: Recent Cases Raise Possible Obstacles" (2010) 13 Potchefstroom Elec LJ 27.

David Kirkpatrick "Property rights: Do you have any?" in Trevor DayaWinterbottom (ed) Frontiers of Resource Management Law (Thomson Reuters, Wellington, 2012).

Martin Loughlin "Rights Discourse and Public Law Thought in the United Kingdom" in GW Anderson (ed) Rights and Democracy: Essays in UK-Canadian Constitutionalism (Blackstone Press, London, 1999).

Jordi Jaria i Manzano "The rights of nature in Ecuador: and opportunity to reflect on society, law and environment" in Robert $V$ Percival, Jolene Lin and William Piermattei (eds) Global Environmental Law at a Crossroads (Edward Elgar, Cheltenham 2014).

James R May and Erin Daly "The Future We Want and constitutionally enshrined procedural rights in environmental matters" in Robert V Percival, Jolene Lin and William Piermattei (eds) Global Environmental Law at a Crossroads (Edward Elgar, Cheltenham 2014).

Danny Nicol The Constitutional Protection of Capitalism (Hart Publishing, Oxford, 2010).

Clare Ovey and Robin CA White Jacobs and White The European Convention on Human Rights ( $4^{\text {th }}$ ed Oxford University Press, Oxford, 2006).

Geoffrey Palmer Environment: The International Challenge (Victoria University Press, Wellington, 1995).

Geoffrey Palmer "The Resource Management Act Reforms: A return to Unbridled Power?" (paper presented to Environmental Defence Society Conference, Auckland, 7 August 2013). 
IUCN Academy of Environmental Law $14^{\text {th }}$ Colloquium University of Oslo Norway 20-25 June 2016

Geoffrey Palmer and Andrew Butler A Consitution for Aotearoa New Zealand (Victoria University Press, Wellington, 2016).

Eduardo M Peñalver Land Virtues (Yale Legal Theory Workshop, New Haven, 2009).

Suri Ratnapala "Environmentalism Versus Constitutionalism: A Contest Without Winners" [2007] RM Theory \& Practice 110.

Paul Rishworth and others, The New Zealand Bill of Rights (Oxford University Press, Melbourne, Australia, 2003).

Philippe Sands and others Principles of International Environmental Law (3rd ed, Cambridge University Press, Cambridge, 2012).

Joseph L Sax "Our precious water resources: learning from the past, securing the future" [2009] RM Theory \& Practice 30.

Malcolm N Shaw International Law (6th ed, Cambridge University Press, Cambridge, 2008).

Peter Salmon "Sustainable Development in New Zealand" in Trevor DayaWinterbottom (ed) Justice and the Environment ( $1^{\text {st }}$ edn, Resource Management Law Association, Auckland, 2007).

Dinah Shelton "Human rights and the environment" in Trevor DayaWinterbottom (ed) The Salmon Lectures - Justice and the Environment (2nd edn, Thomson Reuters, Wellington, 2012).

David Sheppard "The Resource Management Act - from principles to practice" in Trevor Daya-Winterbottom (ed) Frontiers of Resource Management Law (Thomson Reuters, Wellington, 2012).

Scott Stephenson "Quasi-Constitutionality and the Question of Convergence" (paper presented to the Global Symposium on Quasi-Constitutionality and Constitutional Statutes, Victoria University of Wellington, 19-20 May 2016).

Michael Taggart "Reinventing Administrative Law" in Nicholas Bamforth and Peter Leyland (eds) Public Law in a Multi-Layered Constitution (Hart Publishing, Oxford, 2003). 
IUCN Academy of Environmental Law $14^{\text {th }}$ Colloquium University of Oslo Norway 20-25 June 2016

Prue Taylor "The relevance of International Environmental Law for Domestic Law" in Peter Salmon and David Grinlinton (eds) Environmental Law in New Zealand (Thomson Reuters, Wellington, 2015).

Jeremy Waldron The Right to Private Property (Clarendon Press, Oxford, 1988).

Ceri Warnock and Nicola Wheen "Introduction" in Brookers Environmental Legislation Handbook (Thomson Reuters, Wellington, 2014).

Mary Warnock Critical Reflections on Ownership (Edward Elgar Publishing, Cheltenham, 2015).

Rivka Weill "Exploring Constitutional Statutes in Common Law Systems" (paper presented to the Global Symposium on Quasi-Constitutionality and Constitutional Statutes, Victoria University of Wellington, 19-20 May 2016).

Lael K Weis "Understanding the Constitutional Function of Directive Principles: The Role of Directive Legislation" (paper presented to the Global Symposium on Quasi-Constitutionality and Constitutional Statutes, Victoria University of Wellington, 19-20 May 2016).

Christian Whata "Environmental Rights in a Time of Crisis: The Canterbury Experience" (11th Annual Salmon Lecture, Auckland, 25 October 2012).

David Young Keeper of the Long View: Sustainability and the PCE (Parliamentary Commissioner for the Environment, Wellington, 2007). 